\title{
Evolution of sex-determining mechanisms in a wild population of Armadillidium vulgare Latr. (Crustacea, Isopoda): competition between two feminizing parasitic sex factors
}

\author{
PIERRE JUCHAULT, THIERRY RIGAUD \& JEAN-PIERRE MOCQUARD \\ Université de Poitiers, Laboratoire de Biologie Animale, CNRS URA 1452, 40, Avenue du Recteur Pineau, F-86022 \\ Poitiers Cedex, France
}

\begin{abstract}
Sex determination in $A$. vulgare may be under the control of two maternally transmitted parasitic sex factors (PSF) that reverse genetic males $(Z Z)$ into functional neo-females. The first PSF is a Wolbachia-like bacterium $(F)$ and the other $(f)$ is probably a sequence of the $F$ bacterial DNA unstably integrated into the host genome. In the Niort population (France), where these two PSF are mixed, the frequency of neo-females harbouring $f$ increased over a period of 23 years, at the expense of neo-females harbouring $F$. As the maternal transmission to offspring is higher for $F$ than for $f$, the evolution of the $F / f$ ratio disagrees with theoretical models involving a cytoplasmic factor. We show that an autosomal masculinizing gene $(M)$ allows a high rate of paternal transmission of $f$, which could explain the spread of this factor in the population.
\end{abstract}

Keywords: endocytobiote, masculinizing gene, maternal and paternal transmission, sex factor, sex ratio.

\section{Introduction}

Abnormal sex ratios (different from $1 \sigma^{*}: 1 \%$ ), due to sex determining mechanisms that are very different to homo-heterogamety, are known in gonochoric animals (L. D. Hurst, unpublished results). In two orders of Crustacea, parasitic sex factors (PSF) override sex factors carried by heterochromosomes. The term 'parasitic' must be understood in its broader sense, i.e. as defined by Dogiel (1964), 'organisms which use other living organism as their environment and relinquish to their host the task of regulating their relationships with the external environment'. This term has been extended to DNA sequences by Hickey (1982), in a model for the origin of sex.

In both Amphipoda Gammarus duebeni and Orchestia gammarellus, PSF are related to Protozoa, and their main effect is to transform genetic males into functional neo-females (Bulnheim, 1978; GinsburgerVogel et al., 1980).

The most studied example of sex determination by PSF is the terrestrial Isopoda Armadillidium vulgare (pill-bug). In this crustacean, it has been shown experimentally that sex is determined by a male homogamety $(Z Z)$ and a female heterogamety (WZ) (Juchault \&
Legrand, 1972). However, in most populations, female sex is under the control of two distinct PSF, whose effects are very close (review in Juchault \& Legrand, 1989). The first is a symbiotic feminizing Wolbachialike bacterium $(F)$ carried by females (Rigaud et al., 1991b). Bacteria are located in the cytoplasm of the host cells, especially in oocytes, and are only transmitted maternally. Their main effect is to reverse genetic males $(Z Z)$ into functional neo-females $(Z Z+F)$, or sometimes into intersexes. These intersexes are of two types: on the one hand female intersexes $(i F)$, which have a female physiology but possess small male external characters, and, on the other, male intersexes $(i M)$, which are sterile and possess developed male external characters. The second PSF (named $f$ ) has the same feminizing properties and also reverses genetic males into neo-females $(Z Z+f)$. No $i F$ or $i M$ intersexes are produced in progenies of such neo-females. While $f$ is primarily maternally transmitted, paternal transmission has occasionally been observed. Moreover, a $f$ transmission by neo-males $(=Z Z+f$ neo-females experimentally reversed into functional males) has been reported (Legrand \& Juchault, 1984). The precise nature of $f$ remains unknown, but experimental data suggest that it might 
be a sequence of $F$ bacterial DNA integrated into the host genome, with unstable behaviour (transposable element?). On average, $Z Z+F$ and $Z Z+f$ neo-females produce highly female-biased broods, a consequence of the high maternal PSF transmission.

In populations where $F$ and $f$ are present, there are no genetic females and all individuals are genetic males. Thus the female sex is determined solely by the presence of PSF, and the sex ratio in these populations is often female-biased (Juchault et al., 1980; Juchault \& Legrand, 1981a). In such populations, males are mainly produced by genes of $A$. vulgare, which limit the expression or the transmission of PSF. An autosomal masculinizing gene $(M)$ inhibits the expression of $f$, and partially that of $F$ (Juchault \& Legrand, 1976). This dominant gene is responsible for the appearance of another kind of intersex: functional males with female genital apertures $\left(\sigma^{\circ} \mathrm{og}\right)$. In addition, resistance genes $(R)$ of $A$. vulgare [like those defined by Werren (1987)] allow $Z Z+F$ neo-females to produce highly male biased broods, possibly by decreasing the $F$ transmission (Rigaud \& Juchault, 1992).

Legrand et al. (1987) and Juchault \& Legrand (1989) proposed that the sex-determining mechanism in $A$. vulgare is in permanent evolution. The beginning of this evolution may correspond to the replacement of the homo-heterogametic system by the $F$-determining system, probably after a co-evolutionary process involving a primitive pathogenic form of $F$ bacteria and its host. The $F$ bacteria could have invaded populations due to its high transmission of offspring (near 80 per cent on average). Such a transmission could be regarded as a selective advantage for $F$ opposing the sex factors carried by the W chromosome (Bull, 1983; Rigaud, 1991). The transfer of part of the $F$ DNA into the host genome $(=f)$, and the spread of this new sex factor in populations, would be the final step of this evolution. Consequently, sex determination under the control of an ultimate parasite (a gene) would tend to replace heterochromosomal sex determination.

The main question raised at this model is the following: how can $f$ sex determination replace $F$ in populations? In experimental populations consisting of genetic females and neo-females, it has been shown that the spread of $F$ into newly infected populations occurs less often than the spread of $f$, probably because $Z Z+F$ neo-females are disadvantaged with regard to other types of females (higher mortality when young, lower growth rate) (Juchault \& Mocquard, 1989; Rigaud, 1991). This could explain why $f$ is more frequent than $F$ in wild populations. But in populations where $F$ and $f$ are mixed, what is the evolution of the system?

To try and answer this question, the evolution of sex- determining mechanisms had to be followed for a long period in a wild population where $F$ and $f$ are in competition. For such a study, the population would have to live in a stable and well-limited biotope. The Niort population (France, Deux-Sèvres) fits these criteria: it is located inside the surrounding walls of a public college, so there are few exchanges with external populations. The different kinds of sex factors have already been quantified in this population in 1963 and in 1973 (Juchault et al., 1980), and the study has shown that all females are either $Z Z+F$ or $Z Z+f$ neofemales. In 1986, a new sample was collected. The composition of this population and its evolution over these 23 years (i.e. 23 generations for this population) were studied in the light of recent advances in our understanding of PSF.

\section{Materials and methods}

Individuals were collected on the lawn inside the Niort college, in May 1986.

\section{Investigation of feminizing sex factors in females from the wild population}

Gravid females were reared on moistened soil in small circular plastic boxes (diameter $=8 \mathrm{~cm}$ ), with food provided in excess (lime-tree leaves and carrots). The nongravid females were kept in a plastic tub with the collected males for random mating, they were then isolated after laying eggs into the incubating pouch. The broods $\left(F_{1}\right)$ were thus representative of the female production in this population. Immediately after birth, the offspring were isolated from their mother in a wider rectangular plastic box $(26.5 \times 13.5 \times 6.5 \mathrm{~cm})$ to avoid mortality due to high densities. Offspring were sexed 16 weeks later and the males and the females were then separated.

In order to obtain a sex ratio distribution, the offspring from all broods of each mother were added. Progenies were distributed according to the male proportion $(=\operatorname{sex}$ ratio) i.e. $\delta+\delta o g /$ total of offspring. They were classified as female-biased (thelygenous $=\mathrm{T}$ ) or male-biased (arrhenogenous $=\mathrm{AR}$ ) if their sex ratio deviated significantly from $0.5\left(\chi^{2}\right.$-test, $P=0.05)$. If they did not significantly differ from 0.5 they were classified as amphogenous $(=\mathrm{A})$ (Vandel, 1941). A regression method was used to obtain a mean male ratio (MMR) for a type of female (harbouring $F$ or $f$ ), and a comparison between types was made with an analysis of covariance and the Snedecor $F$ test. This method has previously been described (Rigaud et al., 1991a).

A test was performed in order to ascertain the 
presence or the absence of $F$ in the female tissues. The test was based on the fact that a female harbouring $F$ cannot be masculinized by implantation of an androgenic gland (which is responsible for the male hormone synthesis), while genetic females or $Z Z+f$ neo-females are sensitive to this hormone (Juchault \& Legrand, 1981a).

\section{Investigation of sex factors transmitted by the males from the $F_{1}$}

To investigate the frequency of transmission of the masculinizing gene $(M)$ or the $f$ feminizing factor by males from the Niort population, males from $F_{1}$ were paired with genetic females from a population free of PSF (Nice, France). More than one male was tested for each progeny when the progeny size was large and arrhenogenous. The number of males tested was proportional to the male proportion in these progenies, and this number was representative of the males that would have reproduced in the wild population. These crosses and their products were called 'test' crosses and 'test' broods. Other tests were also performed in order to determine the mode of transmission by males of the $f$ feminizing factor.

\section{Results}

Individuals (223) were collected in 1986: $63 \delta^{\prime}+148$ o $+9 i F+1 i M+2$ ơog. Eighty-one females produced $F_{1}$ progenies, which were classified according to their percentage of males + males og (Fig. 1). The $F_{1}$ progenies had a clear female-biased distribution: 25780 o $+6166 q+402 i F+96 i M+129$ o og.

\section{Feminizing sex factors in females from the wild population}

Implantation of an androgenic gland into mothers showed that about 31 per cent of the females harboured $F$ bacteria. Most of these $Z Z+F$ neofemales gave thelygenous progenies (Table 1 and Fig. 1). Among the 56 females sensitive to male hormone, 46 produced progenies with a significantly biased sex ratio (Table 1). The 10 other neo-females produced amphogenous progeny when totalled over broods, but seven females exhibited significantly different sex ratios in successive broods: the first brood was generally thelygenous, then the male ratio increased in the following broods. This phenomenon, called allelogeny, has often been observed in progenies of $Z Z+f$ neo-

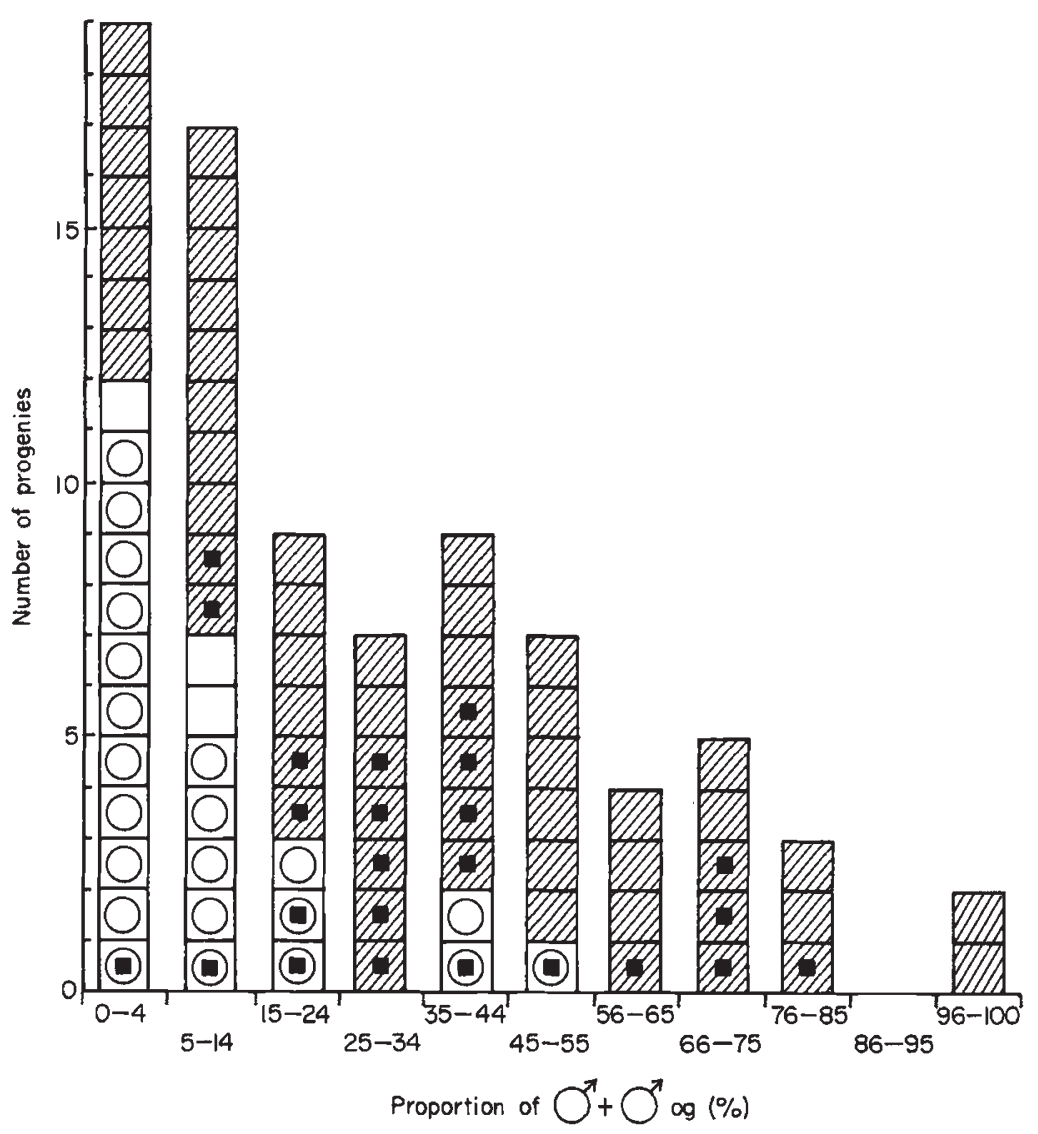

Fig. 1 Distribution of the $F_{1}$ according to their proportion of $\sigma^{\prime}+\sigma^{1} \mathrm{og}$. ( Progenies of females masculinized by an androgenic gland. (ㅁ) Progenies of females non-masculinized by an androgenic gland. (O) Presence of $i F$ or $i M$ intersexes in progeny. ( $)$ Presence of intersexed males ( $\left.\sigma^{\circ} \mathrm{og}\right)$ in progeny. 
Table 1 Sex ratio of progenies in females experimentally masculinized or nonmasculinized by an androgenic gland

\begin{tabular}{llllllll}
\hline & & \multicolumn{3}{l}{ Progenies } & & MMR \pm S.E.M. & \\
\cline { 3 - 5 } & $n$ & $\mathrm{~T}$ & $\mathrm{~A}$ & $\mathrm{AR}$ & $(\%)$ & $F$-test \\
\hline $\begin{array}{l}\text { Masculinized } \\
\quad \text { females }\end{array}$ & 56 & 34 & 10 & 12 & $36.7 \pm 3.8$ & $F=20.04$ \\
$\begin{array}{c}\text { Non-masculinized } \\
\text { females }\end{array}$ & 25 & 23 & 2 & 0 & $9.7 \pm 2.6$ & $(P<0.01)$ \\
\hline
\end{tabular}

$n=$ Number of females; $\mathrm{T}=$ thelygenous progenies; $\mathrm{A}=$ amphogenous progenies; $\mathrm{AR}=$ arrhenogenous progenies; $\mathrm{MMR}=$ mean male ratio in progenies of the two categories of females (an $F$ test was performed to compare these two MMR).

females (Legrand \& Juchault, 1984). Thus, owing to their biased sex ratios, it can be asserted that 53 of the 56 masculinized females were $Z Z+f$ neo-females. As Juchault et al. (1980) have demonstrated that genetic females have disappeared in this population, it could be suggested that the three masculinized females producing amphogenous broods were $Z Z+f$ neo-females, and that amphogeny was probably a pseudo-amphogeny (i.e. amphogeny due to an $f$ transmission of about 50 per cent).

The mean male ratios were significantly different between the progenies of $Z Z+F$ and $Z Z+f$ neofemales (Table 1).

\section{Sex factors transmitted by males from the $F_{1}$}

Forty-nine males from $33 \mathrm{~F}_{1}$ broods $\left(28 \mathrm{~F}_{1}\right.$ broods from $Z Z+f$ neo-females and five $\mathrm{F}_{1}$ broods from $Z Z+F$ neo-females) were paired with genetic females ('test' crosses) (Table 2). Thirty-one crosses were amphogenous and devoid of intersexed males ( $\left.{ }^{\circ} \mathrm{og}\right)$. They corresponded to crosses between genetic females with males free of the masculinizing gene $(M)$ and feminizing factors. oog were found in $14 Z Z+f$ 'test' broods and four $Z Z+F$ 'test' broods. As these intersexed males are individuals harbouring the masculinizing gene $M$, we can conclude that $M$ was present in the genome of their fathers. In theory, such a cross would produce the following progeny (Rigaud, 1991):

$$
\begin{aligned}
& \text { of } \mathrm{ZZMm} \times \text { \& } \mathrm{WZ} \mathrm{mm}
\end{aligned}
$$

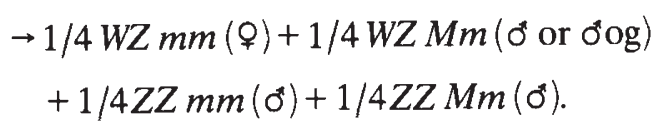

However, most broods harbouring $M$ had a female proportion higher than the theoretical value of $1 / 4$ (Table 2), both in 'test' broods from $Z Z+f$ or $Z Z+F$ neo-females. In the crosses where males issued from $Z Z+f$ neo-females, there was a positive correlation between the female ratio in the $F_{1}$ broods and the female ratio in the 'test' broods $(r=0.66 ; P<0.01$, after the appropriate arcsine transformation of the data). As the female ratio in 'test' broods never exceeded 50 per cent, the interpretation of this correlation would be that the higher the female ratio in $F_{1}$, the closer the female ratio in 'test' broods is to 50 per cent. This surplus of females in 'test' broods could not be produced by the $W Z$ mothers which were free from parasitic sex factors. Thus, it seems that the father carried a factor capable of feminizing a part of his offspring. Such a conclusion is only viable for males harbouring $M$, as no sex ratio deviation was observed in 'test' broods of males free from the $M$ gene.

Further tests were performed, as follows.

1 In order to verify the transmission of a feminizing factor in addition to the masculinizing gene, males from the $F_{1}$ brood IA 865 were paired with genetic females. Fifteen oog were chosen as fathers because their intersex status proved the presence of $M$ in their genome. Because they produced broods with an excess of females compared with the theoretical proportion of $1 / 4$ (Table 3 ), crosses showed that almost all these ofog transmitted a feminizing factor. Here again, the female ratio never exceeded 50 per cent significantly.

If the hypothesis of a transmission of a feminizing factor by the males is correct, two types of daughter would be produced, as described in the following equation (where $\left.{ }^{*}\right]$ represents the feminizing factor).

$$
\begin{aligned}
& Z Z M m[*]\left(\sigma^{*} \text { or } \sigma^{*} \circ g\right) \quad W Z m m[*](\%)+Z Z m m[*](\%) \\
& W Z m m\left(\text { \&) } \quad+W Z M m[*]\left(\sigma^{\circ}\right. \text { or ơog) }\right. \\
& \left.+Z Z M m{ }^{*}\right]\left(0^{*}\right)
\end{aligned}
$$

This cross could never have more than 50 per cent of females, as in the experimental crosses. If the feminizing factor was not transmitted, the proportion of females would be near 25 per cent, which probably occurred in two broods (Table 3 ). 
Table 2 Results of crosses ơ $\mathrm{F}_{1} \times q \mathrm{WZ}$ ('test' crosses). The $\sigma^{\prime} \mathrm{F}_{1}$ issued from the $f$ strain (upper part of the table) or the $F$ strain (lower part of the table)

\begin{tabular}{|c|c|c|c|c|c|c|c|}
\hline \multirow{2}{*}{$\begin{array}{l}\text { Category of } \\
\text { neo-female }\end{array}$} & \multirow[b]{2}{*}{$F_{1}$ number } & \multirow{2}{*}{$\begin{array}{l}\text { } \text { in } F_{1} \text { brood } \\
(\%)\end{array}$} & \multicolumn{3}{|c|}{$\sigma^{\prime \prime} \mathrm{F}_{1} \times \% \mathrm{WZ}$ ('test') } & \multirow{2}{*}{$\begin{array}{l}\text { } \text { in 'test' } \\
\text { brood }(\%)\end{array}$} & \multirow[b]{2}{*}{$\chi^{2}$} \\
\hline & & & $\sigma$ & q & otog & & \\
\hline \multirow[t]{43}{*}{$Z Z+f$} & IA 828 & 85.1 & 50 & 52 & 27 & 40.3 & $* *$ \\
\hline & IA 825 & 80.7 & 35 & 44 & 7 & 51.1 & ** \\
\hline & IA 845 & 71.4 & 40 & 28 & 1 & 40.6 & $*$ \\
\hline & IA 833 & 68.9 & 13 & 39 & 25 & 50.6 & $* *$ \\
\hline & IA 858 & 63.9 & 89 & 67 & 7 & 41.1 & $* *$ \\
\hline & IA 865 & 63.8 & 63 & 64 & 16 & 43.8 & $* *$ \\
\hline & IA 875 & 62.8 & 28 & 35 & 10 & 47.9 & $* *$ \\
\hline & IA 827 & 60.5 & 18 & 30 & 12 & 50.0 & $* *$ \\
\hline & IA 887 & 57.7 & 58 & 59 & - & A & \\
\hline & IA 822 & 55.8 & 48 & 45 & - & A & \\
\hline & IA 855 & 47.4 & 38 & 53 & - & A & \\
\hline & & & 54 & 56 & - & A & \\
\hline & IA 894 & 47.3 & 20 & 23 & - & A & \\
\hline & IA 834 & 46.9 & 47 & 59 & - & A & \\
\hline & & & 22 & 21 & - & A & \\
\hline & IA 826 & 46.8 & 49 & 33 & 8 & 36.0 & ns \\
\hline & IA 861 & 45.8 & 78 & 82 & - & A & \\
\hline & IA 817 & 44.4 & 44 & 46 & - & A & \\
\hline & & & 22 & 23 & - & A & \\
\hline & IA 869 & 42.9 & 21 & 17 & - & A & \\
\hline & IA 820 & 40.2 & 20 & 29 & - & A & \\
\hline & & & 43 & 27 & - & A & \\
\hline & IA 876 & 36.8 & 121 & 87 & 22 & 37.8 & * \\
\hline & IA 824 & 35.8 & 53 & 61 & - & A & \\
\hline & & & 85 & 71 & - & A & \\
\hline & IA 823 & 32.9 & 34 & 40 & - & A & \\
\hline & & & 27 & 28 & - & A & \\
\hline & IA 890 & 31.5 & 81 & 43 & 13 & 31.4 & ns \\
\hline & & & 17 & 50 & 25 & 54.3 & $* *$ \\
\hline & IA 829 & 25.0 & 74 & 73 & - & A & \\
\hline & & & 63 & 75 & - & A & \\
\hline & IA 847 & 20.9 & 23 & 25 & - & A & \\
\hline & & & 74 & 78 & - & A & \\
\hline & IA 839 & 19.6 & 63 & 71 & - & A & \\
\hline & IA 846 & 18.6 & 192 & 147 & - & A & \\
\hline & IA 863 & 1.3 & 26 & 31 & - & A & \\
\hline & & & 32 & 26 & - & A & \\
\hline & IA 856 & 1.0 & 107 & 41 & 17 & 24.8 & ns \\
\hline & & & 58 & 22 & 6 & 25.6 & ns \\
\hline & & & 46 & 33 & - & A & \\
\hline & & & 34 & 27 & - & A & \\
\hline & & & 68 & 79 & - & A & \\
\hline & & & 52 & 55 & - & A & \\
\hline \multirow[t]{6}{*}{$\mathrm{ZZ}+\mathrm{F}$} & IA 864 & 89.3 & 59 & 51 & - & A & \\
\hline & IA 831 & 78.8 & 118 & 43 & 24 & 23.2 & ns \\
\hline & IA 850 & 63.6 & 67 & 70 & 65 & 34.6 & $*$ \\
\hline & IA 872 & 62.7 & 18 & 15 & - & A & \\
\hline & IA 835 & 52.8 & 101 & 38 & 1 & 26.2 & ns \\
\hline & & & 73 & 35 & 22 & 27.1 & ns \\
\hline
\end{tabular}

In bold and italics: 'test' broods including ơ og (for these broods, $\chi^{2}$ was performed to test the similarity of the female rate with the theoretical proportion of $1 / 4$; ns $=$ non-significant; $\left.{ }^{*} P<0.05 ; * * P<0.01\right) ; \mathrm{A}=$ Amphogenous sex ratio. 
Table 3 Distribution of sexual phenotypes in crosses between of og of the $F_{1}$ number IA 865 and genetic females (WZ) of the Nice population

\begin{tabular}{|c|c|c|c|c|}
\hline \multicolumn{3}{|c|}{ ठ og $F_{1} \times \subsetneq \mathrm{WZ}$} & \multirow[b]{2}{*}{ Q (\%) } & \multirow[b]{2}{*}{$\chi^{2}$} \\
\hline రొ & क & ర̋og & & \\
\hline 55 & 40 & 11 & 34.8 & $*$ \\
\hline 193 & 121 & 25 & 35.7 & $* *$ \\
\hline 44 & 44 & 7 & 46.3 & $* *$ \\
\hline 24 & 32 & 26 & 39.0 & ns \\
\hline 108 & 106 & 22 & 44.9 & ** \\
\hline 47 & 42 & 7 & 43.7 & ** \\
\hline 63 & 46 & 3 & 42.1 & $* *$ \\
\hline 44 & 31 & 15 & 34.4 & ns \\
\hline 34 & 32 & 2 & 47.0 & ** \\
\hline 90 & 132 & 48 & 48.9 & $* *$ \\
\hline 88 & 71 & 8 & 42.5 & $* *$ \\
\hline 34 & 53 & 31 & 44.9 & ** \\
\hline 16 & 27 & 9 & 51.9 & $* *$ \\
\hline 51 & 52 & 9 & 46.4 & ** \\
\hline 9 & 15 & 3 & 55.5 & $* *$ \\
\hline
\end{tabular}

$\chi^{2}=$ test of similarity between the experimental female rate and the theoretical proportion of $1 / 4 ; \mathrm{ns}=$ non-significant; ${ }^{*} P<0.05 ;{ }^{* *} P<0.01$.

Table 4 Distribution of sexual phenotypes in crosses between males from the Nice population and females issued from 'test' broods, in $F$ and $f$ strains

\begin{tabular}{|c|c|c|}
\hline \multicolumn{2}{|c|}{ ơ $Z Z \times \odot$ 'test' } & \multirow{2}{*}{$\begin{array}{l}\text { Category of } \\
\text { the brood* }\end{array}$} \\
\hline ర & q & \\
\hline \multicolumn{3}{|c|}{$\begin{array}{l}\text { Mothers issued from 'test' } \\
\text { brood number IA } 850 \text { ( } F \text { strain })\end{array}$} \\
\hline 22 & 28 & A \\
\hline 46 & 47 & A \\
\hline 19 & 29 & A \\
\hline 67 & 13 & $\mathrm{AR}$ \\
\hline 31 & 42 & A \\
\hline 59 & 16 & $\mathrm{AR}$ \\
\hline 20 & 40 & $\mathrm{~T}$ \\
\hline \multicolumn{3}{|c|}{$\begin{array}{l}\text { Mothers issued from 'test' } \\
\text { brood number IA } 890 \text { ( } f \text { strain })\end{array}$} \\
\hline 75 & 3 & AR \\
\hline 36 & 57 & $\mathrm{~T}$ \\
\hline 50 & 0 & AR \\
\hline 44 & 37 & A \\
\hline 44 & 54 & A \\
\hline 20 & 23 & $\mathrm{~A}$ \\
\hline 68 & 5 & AR \\
\hline 77 & 21 & $\mathrm{AR}$ \\
\hline
\end{tabular}

*Determined after a $\chi^{2}$-test. $A=$ amphogenous; $\mathrm{AR}=$ arrhenogenous; $\mathrm{T}=$ thelygenous.
2 Females from two 'test' broods, where an excess of females have been observed, were paired with males free of feminizing or masculinizing factors (Nice population). These females were taken from broods of $Z Z+f$ and $Z Z+F$ neo-females (Table 4). None of the broods carried ong, which confirms the genotype $[\mathrm{mm}]$ of the parents. Approximately half of the broods were not amphogenous, both in the $f$ and in the $F$ strain. The only way to explain the arrhenogenous broods (one of them was female-free) would be to assume that some $\sigma^{\prime \prime} Z Z \times$ o $Z Z$ crosses occur. Such $Z Z$ neo-females could have a female phenotype only in the presence of a feminizing factor $(F$ or $f)$, but these neofemales did not transmit this factor to their offspring. On the contrary, some of their sisters produced thelygenous broods. They could be the result of both genetic females $(W Z)$ or neo-females $(Z Z)$, transmitting a feminizing factor. The genotype of mothers producing amphogenous progenies was also ambiguous. It could be the genotype of genetic females free from feminizing factor, or that of neo-females transmitting this factor to half of their offspring. However, the fact that some females possessed a $Z Z$ genotype and some of their sisters produced thelygenous broods shows that a feminizing factor was transmitted by their father in both $f$ and $F$ strains. In all of these progenies, females were masculinized by androgenic gland

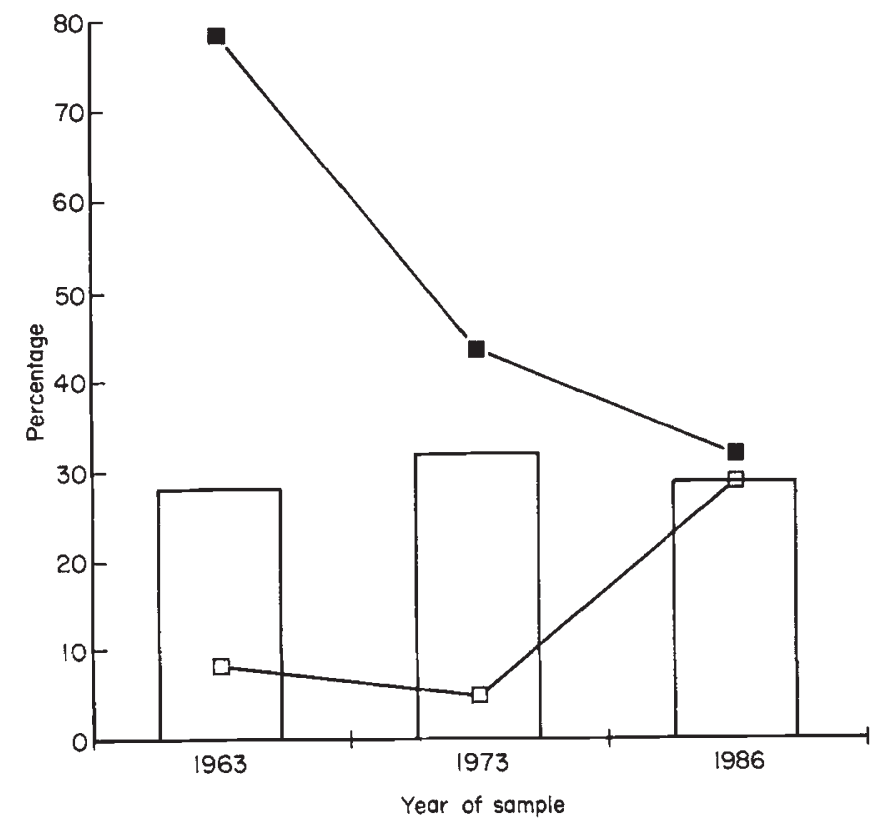

Fig. 2 Characteristics of the Niort population in 1963, 1973 and 1986 . Bars $=$ percentages of $\sigma^{\circ}+\sigma^{\prime} \mathrm{og}$ in the wild population $(n=1478$ in 1963, $n=281$ in 1973 and $n=223$ in 1986). . Lines $=$ percentages of $Z Z+F$ neo-females among mothers in $F_{1}$ broods $(-)$ and percentages of $F_{1}$ broods harbouring ơ og (ㅁ) $(n=63$ in 1963,n=79 in 1973 and $n=81$ in 1986). 
implants. Thus the remaining factor they harboured could only be the $f$ factor.

\section{Comparison of samples collected in 1963, 1973 and 1986 in the Niort population}

This comparison was made from previous data (Juchault et al., 1980). The thelygenous sex ratio in the wild population was relatively stable throughout these 23 years (Fig. 2$)\left(\chi^{2}=1.38 ; 2\right.$ d.f.; $\left.P=0.50\right)$. The $Z Z+F$ neo-female ratio decreased rapidly between 1963 and $1973\left(\chi^{2}=14.4 ; P=1.5 \times 10^{-4}\right)$, then more slowly during the following years $\left(\chi^{2}=2.33 ; P=0.13\right)$. It seems therefore that the $f$ factor tended to spread in the population to the detriment of the $F$ bacteria (Fig. 2). At the same time, the proportion of broods harbouring olog greatly increased during the 1973-1986 period $\left(\chi^{2}=16.7 ; P=4.3 \times 10^{-5}\right)$, although it had been stable during the preceding 10 years $\left(\chi^{2}=0.49 ; P=0.48\right)$ (Fig. 2). As this proportion is the expression of the presence of the $M$ gene, the presence of this gene in the population was greater in 1986 than it was in the preceding years.

\section{Discussion}

The $f$ factor tended to replace the $F$ bacteria as the main sex-determining factor in the Niort population during the period 1963-1986. The decrease in $F$ is paradoxical considering that, on average, $Z Z+F$ neofemales produced more thelygenous broods than $Z Z+f$ neo-females. Theoretical models computed by Bull (1983) and Taylor (1990) show that when two feminizing parasitic sex factors (PSF) are in competition, the female category that produces the most thelygenous progenies spreads in the population. The PSF they harbour then becomes the main sex factor. In the Niort population, however, the less productive factor became predominant. In other populations where the two feminizing factors are present, the $f$ factor is always the most frequent (Juchault \& Legrand, 1981a and unpublished data).

The high frequency of the $M$ gene is an explanation for the weak thelygeny of the $Z Z+f$ neo-females in 1986. $M$ is a gene which efficiently prevents the expression of the $f$ factor, and induces the production of males in broods of $Z Z+f$ neo-females. This masculinizing gene is less efficient against the $F$ bacteria, and its main effect is to induce the production of $i F$ or $i M$ intersexes in the broods of $Z Z+F$ neo-females (Legrand et al., 1974; Rigaud, 1991). Taylor (1990) showed that an autosomal gene repressing a strong feminizing factor must be selected in a thelygenous population, in order to avoid too small a male ratio. In the Niort population, the increase in the $M$ masculinizing gene came logically after the increase in the $f$ feminizing factor against which this gene is efficient.

However, we have shown that in the $f$ strain, 83 per cent of males harbouring $M$ carried $f$ and transmitted this factor to a part of their offspring. In such males, $f$ expression could have been inhibited by $M$, whereas $f$ transmission could still have been possible. The correlation between the proportion of females in the $\mathrm{F}_{1}$ progenies and the proportion of females in the 'test' broods strengthens this hypothesis. As we saw in the 'test' crosses, individuals harbouring $M$ were heterozygous for this gene. Thus, in males with a $[\mathrm{Mm}]$ genotype, some $[\mathrm{Zm}]+f$ spermatozoids should be produced and should be able to transmit the active form of $f$. The $M$ gene, which seems to be a gene selected against $f$ in populations, might enhance the transmission of the $f$ by allowing it to use the paternal route. Such a paternal transmission of $f$ has been observed by Legrand \& Juchault (1984) in another population but with a lower frequency. Males harbouring $M$ and transmitting $f$ have also been observed in the Niort $F$ strain. This phenomenon may be explained by the hypothesis of Juchault \& Legrand (1989): the $F$ bacteria should be able to transfer a part of its genetic information (transposon or plasmid) into its host genome (the DNA sequence transferred should include genes responsible for the feminizing properties, i.e. the inhibition of male genes). In such a condition, oocytes of $Z Z+F$ neo-females might harbour the $f$ factor. As $f$ inhibits the male factors of the $\mathrm{Z}$ chromosome, eggs harbouring $f$ develop a female phenotype, unless its genome harbours $M$. In this case, the sexual differentiation leads to a male or a ofog capable of transmitting $f$ as described before.

However, the $f$ factor carried by males seems to be poorly transmitted by their daughters. This phenomenon has been observed by Juchault \& Legrand (1984) in crosses between individuals from two distinct populations, which is the case in our experiments. A decrease in the $f$ maternal transmission was also observed when individuals from different populations were mated (Juchault \& Legrand, 1976). These results suggest that a genetic mechanism could favour the transmission of the $f$ factor.

From these observations, and relying on the evolution model proposed by Juchault \& Legrand (1989), the evolution of the $f$ and $F$ factors, when they are in competition in a wild population, could be drawn as follows. The appearance and the maintenance of $F$ bacteria in a population free from PSF could be the beginning of this evolution. The transfer of a part of the bacterial genetic information in the genome of the host would appear relatively frequently in such a population 
but this transfer would be masked by the presence of $F$. If $F$ is maintained in the population, the spread of this factor could be ineluctable, so the population would evolve toward thelygeny (Rigaud et al., 1992). As soon as the increase in thelygeny occurs, the regulation of $F$ transmission by resistance genes $(R)$ would be progressively selected (Rigaud \& Juchault, 1992). Oocytes free from $F$ would then induce both the appearance of males, when $f$ is not transferred, and the appearance of $Z Z+f$ neo-females when this transfer occurs. At the same time, genetic females should progressively be eliminated by the two categories of neo-females, owing to the high transmission of PSF. The Niort population in 1963 could correspond to a population in which the disappearance of genetic females was relatively recent because $F$ was the majority. The selection of the $M$ gene would occur later in the $f$ strain according to a frequency-dependent model. However, even if the presence of $M$ induced the appearance of male phenotypes, the feminizing factor could always be present in these males and could be transmitted as described before. Such males carrying $f$ and $M$ could then mate with allelogenous $Z Z+f$ neo-females or $Z Z+F$ neo-females carrying $R$ genes. The synergetic effects of $M$ and $R$ genes could then enhance the number of individuals transmitting $f$. This phenomenon might explain why $f$ increased in the population, although the $f$ transmission by the maternal route could be lower than the $F$ transmission. Furthermore, other phenomena, such as the competitive load of the $Z Z+F$ neo-females (Rigaud, 1991), could enhance the decrease in $F$ and facilitate $f$ spreading.

Thus, $f$ seems to be able to eliminate $F$ in populations where these two factors are in competition. In a way, when $F$ bacteria transfers the $f$ factor into its host genome, it commits suicide. In such a population, the $f$ factor is destined to become the unique sex factor allowing female differentiation. This has been observed in other populations. However, such a process cannot be extended to all populations. Other evolutionary patterns might occur, owing to the great diversity in the composition of $A$. vulgare populations (Juchault \& Legrand, 1981a,b; unpublished data).

\section{References}

BULl, J. J. 1983. Evolution of Sex Determining Mechanisms. Benjamin/Cummings Publ. Co., Menlo Park, CA.

BULNHEIM, H. P. 1978. Interaction between genetic, external and parasitic factors in sex determination of the crustacean amphipod Gammarus duebeni. Helgol. Wiss. Meer., 31, 1-33.

Dogiel, v. A. 1964. General Parasitology. Oliver and Boyd Ltd, Edinburgh, London.
GINSBURGER-VOGEL, T., CARRE-LECUYER, M. AND FRIEDMONTAUfier, M. C. 1980. Transmission expérimentale de la thélygénie liée à l'intersexualité chez Orchestia gammarellus (Pallas). Analyse des phénotypes sexuels dans les descendances de femelles normales transformées en femelles thélygènes. Arch. Zool. Exp. Gén., 122, 261-270.

HICKEY, D. A. 1982. Selfish DNA: A sexually-transmitted nucléar parasite. Genetics, 101, 519-531.

JUCHAUlt, P. AND LEGRAND, J. J. 1972. Croisement de néo-mâles expérimentaux chez Armadillidium vulgare Latr. (Crustacé, Isopode, Oniscoïde). Mise en évidence d'une hétérogamétie femelle. C.R. Acad. Sci. Paris., 274, 1387-1389.

JuChault, P. AND LEGRAND, J. J. 1976. Etude génétique de l'intersexualité des mâles à ouvertures génitales femelles chez l'oniscoïde Armadillidium vulgare Latr.: interprétation et modalités de la transmission héréditaire. C.R. Soc. Biol., 2, 429-433.

JUChault, P. AND LEGRAND, J. J. 1981a. Contribution à l'étude qualitative et quantitative des facteurs contrôlant le sexe dans les populations du Crustacé Isopode terrestre Armadillidium vulgare Latr. II - Populations hébergeant le facteur féminisant $F$ (bactérie intracytoplasmique). Arch. Zool. Exp. Gén., 122,65-74.

JUChault, P. AND LEGRAND, J. J. 1981b. Contribution à l'étude qualitative et quantitative des facteurs contrôlant le sexe dans les populations du Crustacé Isopode terrestre Armadillidium vulgare Latr. III - Populations n'hébergeant pas le facteur féminisant F. Arch. Zool. Exp. Gén., 122, 117-131.

JUCHAULT, P. AND LEGRAND, J. J. 1989. Sex determination and monogeny in terrestrial isopods Armadillidium vulgare (Latreille, 1804) and Armadillidium nasatum (BuddeLund, 1885). Mon. Zool. Ital. (N.S.) Monogr., 4, 359-375.

JUCHAULT, P. LEGRAND, J. J. AND MOCQUARD, J. P. 1980. Contribution à l'étude qualitative et quantitative des facteurs contrôlant le sexe dans les populations du Crustacé Isopode terrestre Armadillidium vulgare Latr. I - La population de Niort (Deux-Sèvres). Arch. Zool. Exp. Gén., 121, 3-27.

JUCHAULT, P. AND MOCQUARD, J. P. 1989. Effet de l'inoculation d'une bactérie endocellulaire féminisante sur la croissance et la reproduction des femelles du Crustacé Oniscoide Armadillidium vulgare (Latr.). Conséquences possibles sur l'évolution des populations. Crustaceana, 56, 84-92.

LEGRAND, J. J. AND JUCHAULT, P. 1984. Nouvelles données sur le déterminisme génétique et épigénétique de la monogénie chez le crustacé isopode terrestre Armadillidium vulgare Latr. Gén. Sél. Evol., 16, 57-84.

LEGRAND, J. J., JUChaUlT, P. AND MocouARD, J. P. 1974. Analyse préliminaire de l'intersexualité féminisante chez le crustacé Armadillidium vulgare Latr. (isopode oniscoïde). C.R. Acad. Sci. Paris., 278, 2979-2982.

LEGRAND, J. J., LEGRAND-HAMELIN. E. AND JUCHAULT, P. 1987. Sex determination in crustacea. Biol. Rev., 62, 439-470.

RIGAUD, T. 1991. Déterminisme extrachromosomique du sexe chez Armadillidium vulgare Latr. (Crustacés, Isopode): Modifications du sex ratio par une bactérie endocytobiotique et conséquences sur l'évolution des génotypes sexuels dans les populations. Thèse d'Université de Tours, $138 \mathrm{pp}$. 
RIGAUD, T. AND JUCHAULT. P. 1992. Genetic control of the vertical transmission of a cytoplasmic sex factor in Armadillidium vulgare Latr. (Crustacea, Oniscidea). Heredity, 68, 47-52.

RIGAUD, T., JUChaUlT. P. AND MocQuaRd, J. P. 1991a. Experimental study of temperature effects on sex ratio of broods in terrestrial crustacea Armadillidium vulgare Latr. Possible implication in natural populations. J. Evol. Biol., 4, 603-617.

RIGAUD, T., MOCQUARD, J, P. AND JUChaULT, P. 1992. The spread of parasitic sex factors in populations of Armadillidium vulgare Latr. (Crustacea, Oniscidea): effects on sex ratio. Gen. Select. Evol., 24, 3-18.
RIGAUD, T., SOUTY-GROSSET, C., RAIMOND, R., MOCQUARD, J, P. AND JUCHAULT, P. 1991b. Feminizing endocytobiosis in the terrestial crustacean Armadillidium vulgare Latr. (Isopoda): recent acquisitions. Endocytobiosis Cell Res., 7, 259-273.

TAYLOR, D. R. 1990. Evolutionary consequences of cytoplasmic sex ratio distorters. Evol. Ecol., 4, 235-248.

VANDEL, A. 1941 Recherches sur la génétique et la sexualité des Isopodes terrestres. VI: Les phénomènes de monogénie chez les Oniscoïdes. Bull. Biol. Fr. Bel., 75, 316363.

WERREN, J. H. 1987. The coevolution of autosomal and cytoplasmic sex ratio factors. J. Theor. Biol., 124, 317-333. 